\title{
Controls on short-term variations in Greenland glacier dynamics
}

\author{
A.V. SUNDAL, ${ }^{1}$ A. SHEPHERD, ${ }^{1}$ M. VAN DEN BROEKE, ${ }^{2}$ J. VAN ANGELEN, ${ }^{2}$ \\ N. GOURMELEN, ${ }^{1 *}$ J. PARK ${ }^{1 \dagger}$ \\ ${ }^{1}$ School of Earth and Environment, University of Leeds, Leeds, UK \\ ${ }^{2}$ Institute for Marine and Atmospheric Research, University of Utrecht, Utrecht, The Netherlands
}

\begin{abstract}
Short-term ice-dynamical processes at Greenland's Jakobshavn and Kangerdlugssuaq glaciers were studied using a 3 day time series of synthetic aperture radar data acquired during the $\mathbf{2 0 1 1}$ European Remote-sensing Satellite-2 (ERS-2) 3 day repeat campaign together with modelled meteorological parameters. The time series spans the period March-July 2011 and captures the first $\sim 30 \%$ of the summer melting season. In both study areas, we observe velocity fluctuations at the lower $\sim 10 \mathrm{~km}$ of the glacier. At Jakobshavn Isbræ, where our dataset covers the first part of the seasonal calving-front retreat, we identify ten calving episodes, with a mean calving-front area loss of $1.29 \pm 0.4 \mathbf{~ k m}^{2}$. Significant glacier speed-up was observed in the near-terminus area following all calving episodes. We identify changes in calving-front geometry as the dominant control on velocity fluctuations on both glaciers, apart from a $<15 \%$ early-summer speed-up at Kangerdlugssuaq Glacier during a period of calving-front advance, which we attribute to enhanced surface melt-induced basal lubrication. Our 3 day velocity maps show new spatial characteristics of the ice melange flow variability in the Jakobshavn and Kangerdlugssuaq fjord systems, which are primarily controlled by calving-front dynamics and fjord geometry.
\end{abstract}

\section{INTRODUCTION}

Recent studies of the Greenland ice sheet (GrIS) have revealed changes in outlet glacier dynamics both on seasonal (Howat and others, 2010; Joughin and others, 2012) and decadal (Rignot and Kanagaratnam, 2006; Moon and others, 2012) timescales. The observed changes have raised concerns over the future stability of the GrlS and stimulated investigations of the processes controlling variability in tidewater glacier dynamics. Advances have been made in terms of process representations within large-scale ice-sheet models, but the spatial resolution of such models is still too coarse to resolve most outlet glaciers, and major deficiencies remain in the representation of processes acting at the marine boundary such as calving (Vieli and Nick, 2011). Some of these issues have been overcome in spatially reduced ice-flow models that are specifically designed for single outlet glacier basins and such model simulations have provided new insights into the dynamic sensitivity of outlet glaciers to different forcing mechanisms (Nick and others, 2009; Joughin and others, 2012). Observations of ice flow, calving-front positions and ice thickness are crucial to validate these modelling results, and acquisition of such datasets at high spatial and temporal resolution is important to capture rapid dynamic changes and determine the timing of potential triggering mechanisms.

Several studies suggest that changes in glacier dynamics are caused by processes that act on the calving front, triggering a retreat and a reduction in the amount of flow resistance generated at the glacier bed and fjord walls (e.g. Joughin and others, 2004, 2008a; Thomas, 2004; Vieli and Nick, 2011). This loss of resistive stresses at the terminus may

*Present address: Institut de Physique du Globe, University of Strasbourg, Strasbourg, France.

†Present address: Department of Earth System Sciences, University of Yonsei, Seoul, Republic of Korea. lead to an increase in ice velocity and thinning that propagates rapidly upstream. Several processes may initiate these changes, such as increased calving due to surface meltinduced hydrofracturing of water-filled near-terminus crevasses (Sohn and others, 1998; Van der Veen, 1998; Benn and others, 2009) or increased melting on the underside of a floating ice tongue, especially close to the grounding line (Holland and others, 2008; Rignot and others, 2010; Straneo and others, 2010; Motyka and others, 2011; Vieli and Nick, 2011). Calving-front retreats have also been correlated with the decay of proglacial ice melange, both on seasonal and longer timescales (Joughin and others, 2008a, 2012), suggesting that the presence of ice melange may help to temporarily stabilize the termini of tidewater glaciers by exerting a backpressure that prevents the overturning of large icebergs (Reeh and others, 2001; Amundson and others, 2010).

Another process that may affect dynamics of outlet glaciers is increased basal sliding caused by drainage of surface meltwater to the ice-bedrock interface via fracture propagation (Zwally and others, 2002; Das and others, 2008). Ice-flow acceleration is believed to occur at times when the input of surface meltwater to the bed exceeds the capacity of the subglacial drainage system (Schoof, 2010). Several studies have revealed that land-terminating margins in western Greenland respond rapidly to variations in surface meltwater generation, temporarily increasing ice flow by $>50 \%$ (Joughin and others, 2008a; Van de Wal and others, 2008; Shepherd and others, 2009; Sundal and others, 2011). Marine-terminating glaciers in Greenland, on the other hand, have generally displayed less sensitivity to variations in runoff (Echelmeyer and Harrison, 1990; Joughin and others, 2008a), although surface melt-induced velocity variations of similar absolute magnitude to those observed on land-terminating margins have been reported (Joughin and others, 2008b; Andersen and others, 2011; Sole and others, 2011).

While the development of interferometric synthetic aperture radar (InSAR) and SAR offset-tracking techniques 


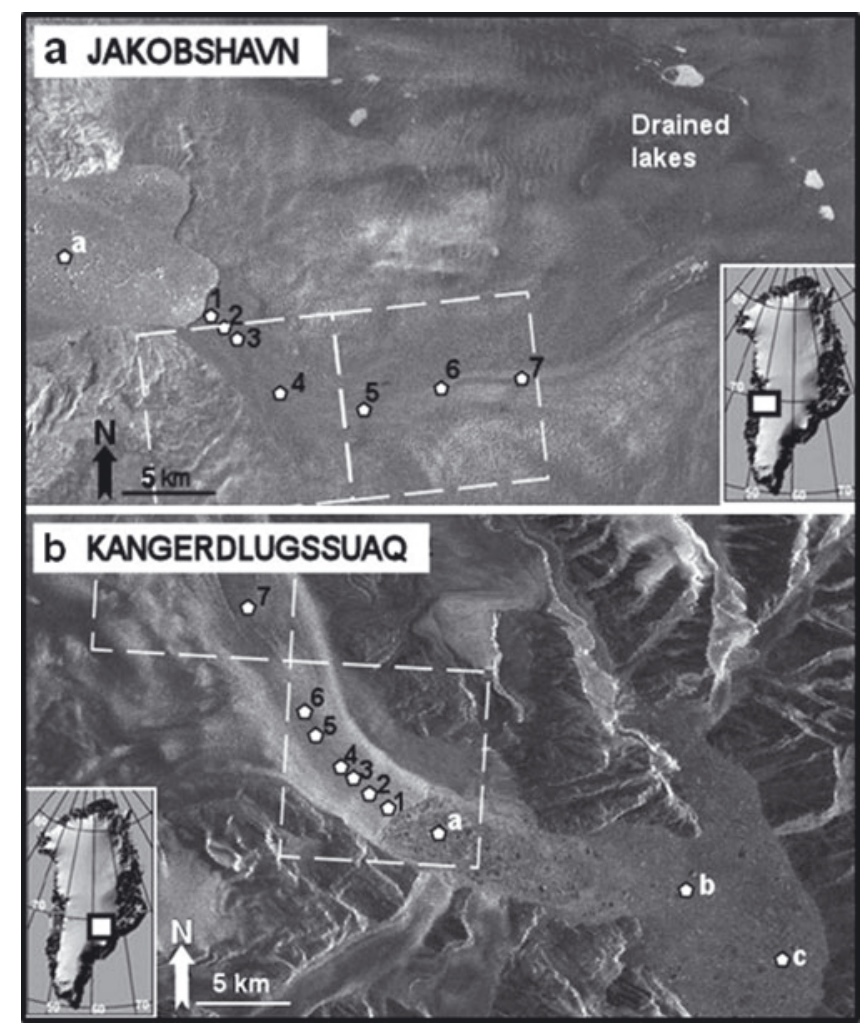

Fig. 1. Map showing (a) Jakobshavn Isbræ and (b) Kangerdlugssuaq Glacier and the locations on each glacier from where velocity data were extracted. White squares show the outline of the Regional Atmospheric Climate Model model gridcells.

have significantly improved our ability to measure and monitor ice motion (e.g. Joughin and others, 2004, 2012; Luckman and others, 2006), infrequent acquisitions of SAR data with short temporal baselines (1-3 days) limit the use of satellite radar data for studies of glacier calving episodes and ice-flow changes occurring over a few days. In March 2011, the European Remote-sensing Satellite-2 (ERS-2) was moved from a 35 to a 3 day repeat orbit where it remained until it was switched off permanently. The campaign acquired SAR data at a temporal resolution of 3 days spanning the period March-July 2011. Acquisitions were made at a limited number of locations around the GrIS margin and covered two of Greenland's largest outlet glaciers: Jakobshavn Isbræ and Kangerdlugssuaq Glacier. Here we explore the ERS-2 3 day dataset acquired over these two glaciers (Fig. 1) in combination with modelled meteorological data to characterize glacier calving episodes and rapid glacier and ice melange flow variability and to assess the sensitivity of the glaciers to short-term environmental changes.

\section{SHORT-TERM DYNAMICS OF JAKOBSHAVN AND KANGERDLUGSSUAQ GLACIERS}

After the loss of the $\sim 15 \mathrm{~km}$ long Jakobshavn ice tongue between 1998 and 2003, a pattern of strong seasonal glacier velocity fluctuations that correlate well with a seasonal cycle of ice-front advance and retreat was recorded (Joughin and others, 2008a, 2012). Observations have shown that the Jakobshavn calving front advances to its maximum forward position by late winter or early spring and retreats to a minimum position by the end of summer, with the rate of iceberg production during summer being almost six times that during the winter (Sohn and others, 1998; Joughin and others, 2008a). Studies of the proglacial ice melange in Kangia Icefjord suggest that the melange contributes to the glacier's seasonal advance and retreat by influencing the timing of calving events (Amundson and others, 2010). In addition to seasonal variations in glacier speed and calving-front position, a pattern of near-terminus winter thickening $(\sim 15 \mathrm{~m})$ and summer thinning $(\sim 30 \mathrm{~m})$ over the period 2006-10 has been reported (Joughin and others, 2012). Recent investigations suggest that the seasonal cycle of ice velocity and thinning is a response to the seasonal varying calving-front position, with an additional contribution from surface melt-induced basal lubrication (Joughin and others, 2012).

Seasonal oscillations in calving-front position are also well documented at Kangerdlugssuaq Glacier, but the timing of the maximum calving-front extent differs from that observed at Jakobshavn Isbræ (Luckman and others, 2006; Joughin and others, 2008c; Seale and others, 2011). Observations during the period 2000-09 show that the Kangerdlugssuaq calving front generally advances to a maximum in midsummer and retreats to a minimum at the end of December or in early January, with a typical difference of $\sim 3 \mathrm{~km}$ between the maximum and minimum position (Seale and others, 2011). Glacier speed-ups have been observed to accompany calving-front retreats, while ice-front advances have been associated with decelerations (Luckman and others, 2006). The Kangerdlugssuaq fjord is typically ice-free between July and December and ice-covered from January to June (Christoffersen and others, 2012).

\section{DATA AND METHODOLOGY}

\section{Surface velocity}

During the ERS-2 3 day repeat campaign, SAR images covering Jakobshavn Isbræ were acquired every 3 days between 12 March and 1 July 2011. From this dataset we formed 373 day image pairs. For Kangerdlugssuaq Glacier, we obtained 32 SAR images between 17 March and 3 July 2011 from which we formed 283 day image pairs. We used SAR feature tracking (Strozzi and others, 2002) to produce ice velocity maps since loss of coherence due to large Doppler centroid differences $(57 \%$ of the image pairs had Doppler centroid differences $>1200 \mathrm{~Hz}$ ), high glacier/ice melange speeds and widespread surface melting limit the use of coherence-based techniques.

SAR feature tracking provides estimates of surface displacement fields by tracking the displacement of common features on the ice surface between two SAR images (Strozzi and others, 2002). The technique relies on cross correlation of image patches between repeat-pass pairs of SAR images separated by a full satellite cycle. We determined the orbital offsets by fitting a bilinear polynomial function of offset fields computed globally from the SAR images assuming no displacement for most parts of the image. The local offsets were determined by finding the peak position of the intensity correlation field between regularly spaced image patches (Strozzi and others, 2002). For the present study we used patch sizes of $128 \times 256$ single-look pixels. Correlation signal-to-noise ratios were used to reject poor matches, and the resulting velocity fields were transformed to map coordinates using the Geoscience Laser Altimeter System/lce, Cloud and land Elevation Satellite (GLAS/ICESat) $1 \mathrm{~km}$ laser altimetry digital elevation model of Greenland (DiMarzio 
and others, 2007). The tracking error was assessed by measuring the mean difference from zero of large samples of tracking data over static rock (Pritchard and others, 2005). A drawback of the feature-tracking technique is the relatively poor accuracy: for the 3 day tracking data used in this study the mean and maximum error was 0.33 and $0.51 \mathrm{~m} \mathrm{~d}^{-1}$, respectively, for the Jakobshavn dataset and 0.44 and $0.52 \mathrm{~m} \mathrm{~d}^{-1}$, respectively, for the Kangerdlugssuaq dataset.

\section{Calving-front position}

Calving-front positions were mapped from the same ERS-2 3 day repeat campaign backscatter images that were used to produce ice velocity maps. We also determined calvingfront positions from available Envisat backscatter images acquired during 2010. Since calving-front retreat is often uneven, with some parts of the front retreating while other parts remain stable, we based our analysis on changes in glacier calving-front area. The area change was determined by manually digitizing the outline of a polygon bounded on the down-glacier edge by the ice-front location at each image acquisition date, on each lateral side by the glacier margins and on the upstream side by the minimum ice-front extent recorded in each time series. The largest uncertainties in the terminus area-change estimates arise from occasional lack of contrast in the backscattered signal between some part of the ice front and the surrounding area. The uncertainty of our calving area loss estimates was calculated by multiplying the area of half a pixel with the number of pixels in the perimeter of the polygon. Since we can only resolve calving episodes to within a 3 day period, we cannot determine whether a single calving episode comprises several small calving events or a single large one.

\section{Modelled meteorological data}

We obtained daily average estimates of near-surface (2 m) air temperature, surface melting, surface runoff and $10 \mathrm{~m}$ wind speed at a horizontal resolution of $\sim 11 \mathrm{~km}$ from the Regional Atmospheric Climate Model (RACMO2) (Van Meijgaard and others, 2008). For the period under consideration here, the model is forced at the lateral boundaries and at the sea surface by European Centre for Medium-Range Weather Forecasts (ECMWF) Interim Re-analysis (ERA-Interim). RACMO2 has been evaluated extensively using in situ observations from manned and automatic weather stations as well as satellite-derived estimates of melting extent, mass changes and drifting snow occurrence (e.g. Van den Broeke and others, 2009; Van Angelen and others, 2012). Owing to the relatively high spatial resolution of RACMO2, Jakobshavn and Kangerdlugssuaq glaciers were covered by several model gridcells. We used data from two gridcells at each glacier covering the lower and upper part of the area from which we extracted ice velocity data (Fig. 1).

\section{RESULTS}

\section{Jakobshavn Isbræ}

Ice velocity evolution throughout the sequence extracted at seven locations $\sim 1.0,2.0,3.0,6.5,12.0,17.0$ and $22.0 \mathrm{~km}$ upstream of the 1 July ice-front position are presented in Figure 2 (locations 1-7, respectively, in Fig. 1a). Near the glacier terminus, we observed a gradual speed-up in the second half of our study period, with velocities increasing from $\sim 32 \mathrm{~m} \mathrm{~d}^{-1}$ to a maximum of $40.9 \mathrm{~m} \mathrm{~d}^{-1}$ (28\% speedup) (Fig. 2). The same pattern of velocity increase was
Table 1. Calving statistics at Jakobshavn (JN) and Kangerdlugssuaq (KL) glaciers. The speed-up is calculated by comparing the average ice velocity over a 6 day period before and after each of the observed calving periods

\begin{tabular}{|c|c|c|c|c|}
\hline \multirow[t]{2}{*}{ Glacier } & \multicolumn{2}{|c|}{ Calving period } & \multirow{2}{*}{$\begin{array}{c}\text { Area loss per } \\
\text { calving period } \\
\mathrm{km}^{2}\end{array}$} & \multirow{2}{*}{$\begin{array}{c}\text { Near-terminus } \\
\text { speed-up } \\
\%\end{array}$} \\
\hline & No. & Date (2011) & & \\
\hline \multirow[t]{10}{*}{ JN } & 1 & 12-15 Mar & $1.68 \pm 0.4$ & No data \\
\hline & 2 & 2-5 Apr & $1.35 \pm 0.3$ & $2.5 \pm 1.0$ \\
\hline & 3 & 11-17 Apr & $1.21 \pm 0.4$ & $2.5 \pm 1.1$ \\
\hline & 4 & 5-8 May & $0.89 \pm 0.4$ & $3.7 \pm 1.0$ \\
\hline & 5 & 17-20 May & $2.64 \pm 0.5$ & $6.0 \pm 1.1$ \\
\hline & 6 & 4-7 Jun & $0.90 \pm 0.3$ & $2.3 \pm 1.0$ \\
\hline & 7 & 10-13 Jun & $0.77 \pm 0.3$ & $7.4 \pm 1.4$ \\
\hline & 8 & 19-22 Jun & $0.91 \pm 0.3$ & $7.5 \pm 1.2$ \\
\hline & 9 & 25-28 Jun & $1.71 \pm 0.4$ & No data \\
\hline & 10 & 28 Jun-1 Jul & $0.85 \pm 0.3$ & No data \\
\hline$K L$ & 1 & 16-22 May & $8.30 \pm 0.7$ & $5.5 \pm 1.4$ \\
\hline
\end{tabular}

observed up to $\sim 10 \mathrm{~km}$ inland, but with decreasing magnitude of the acceleration with increasing distance from the calving front. No significant trend in the velocity evolution was found further upstream within the time period covered by our dataset.

We identified ten calving episodes at Jakobshavn Isbræ between 12 March and 1 July 2011, with a mean and maximum calving-front area loss of $1.29 \pm 0.4$ and $2.64 \pm 0.5 \mathrm{~km}^{2}$, respectively (Fig. 2; Table 1). The calving rate increased in June compared with the earlier months; five of the ten calving episodes occurred between 4 June and 1 July 2011, a mean calving rate of about one calving episode every 5 days. The longest periods of continuous icefront advance lasted 18 days and occurred from 15 March to 2 April and 17 April to 5 May 2011 (Fig. 2). The ice front reached its maximum position on 5 May 2011 when it extended $\sim 1.2 \mathrm{~km}$ downstream of the 1 July position. Observations of seasonal ice-front variations at Jakobshavn Isbræ after 2004 suggest that the calving front reaches its minimum position at the end of the summer (Joughin and others, 2008a, 2012), and Bevan and others (2012) showed that the calving front continued to retreat beyond the minimum position observed within our 2011 time series. Comparison of several frontal positions in spring and early summer 2011 with those of 2010 shows that the calving front was located $\sim 1 \mathrm{~km}$ further downstream in 2011 compared with the previous year, but we are not able to draw conclusions on interannual changes in ice-front positions as we lack late-summer observations.

Possible correlations between calving and ice flow were investigated by comparing the average ice velocity over a 6 day period before and after each of the observed calving episodes. Near the calving front, we found a significant increase in speed after all the calving episodes, ranging from $2.3 \%$ to $7.5 \%$ (Table 1 ). Similarly, we explored a potential correlation between ice-front advance and ice velocity by determining the velocity trend during the three longest periods of continuous ice-front advance within our dataset (excluding a 6 day period after the preceding calving episodes) (Fig. 2). Close to the calving front, we observed either a decreasing ice velocity trend or no significant velocity change during all these periods. Both this pattern and the 


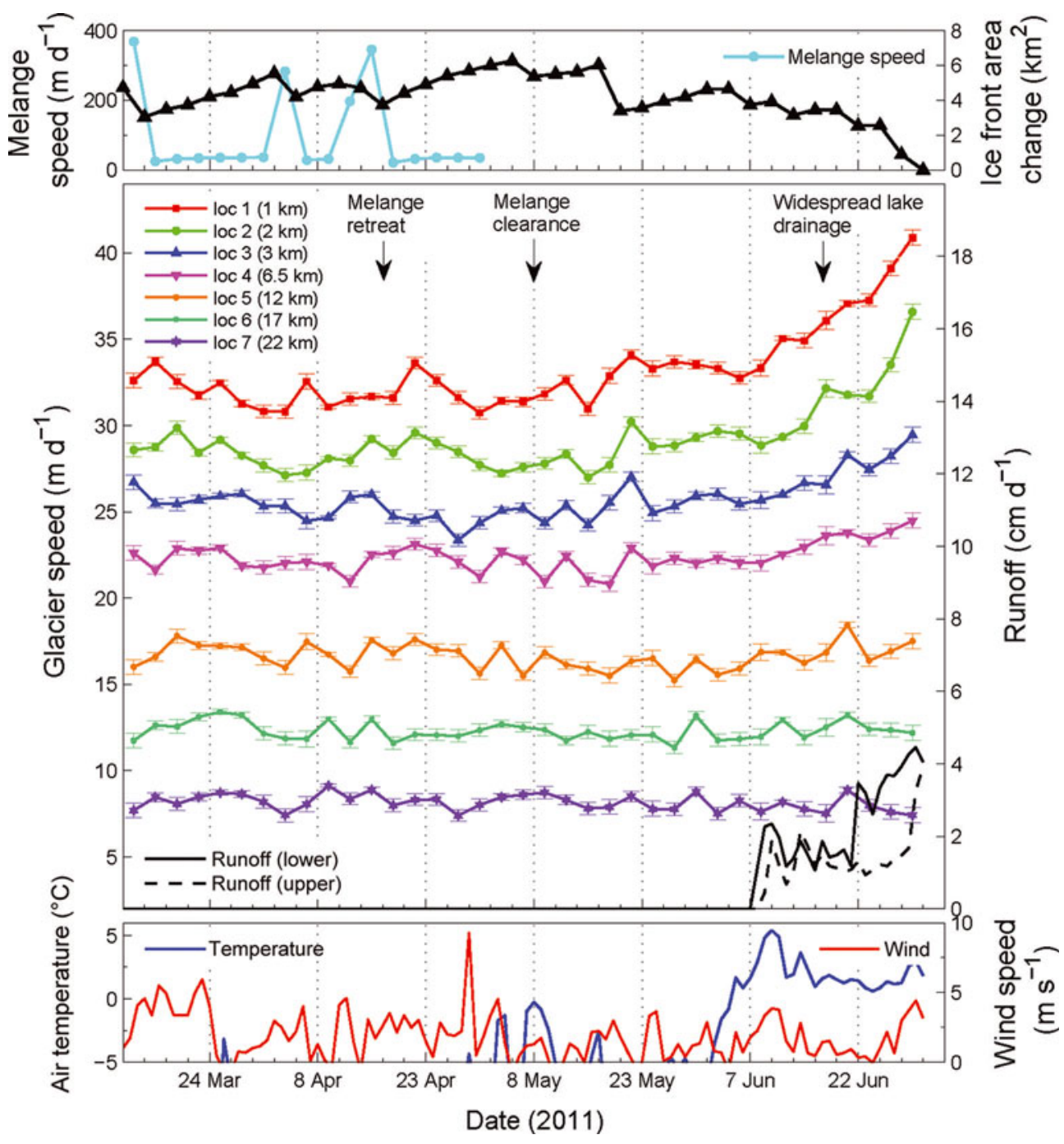

Fig. 2. Fluctuations in glacier velocity, ice melange velocity, calving-front area and modelled meteorological parameters at Jakobshavn Isbræ. The wind vector component is shown in the along-fjord direction. Locations 1-7 and location a from where melange data were extracted are shown in Figure 1. Temperature and wind speed were extracted from the model gridcell covering the lower part of the glacier.

observed speed-up after calving episodes were limited to the near-terminus area (Rosenau and others, in press).

Based on modelled meteorological data, we estimate the 2011 surface meltwater runoff season to commence on 8 June and last until the end of August (Fig. 2). Our velocity dataset covers the first 24 days $(\sim 30 \%)$ of this period during which the surface runoff increased to a maximum of $4.5 \mathrm{~cm} \mathrm{~d}^{-1}$ at the lower part of the glacier. Thereafter surface runoff gradually decreased over the course of the summer (not shown), only interrupted by two $<5$ day periods of high melting in late July and late August generating surface runoff of up to $6.9 \mathrm{~cm} \mathrm{~d}^{-1}$. Based on differences in SAR backscatter intensity values over water-filled and drained supraglacial lakes, we identified a period of widespread lake drainage (at elevations above all the seven locations shown in Fig. 2) between 16 and 19 June, about 10 days after the onset of surface runoff.

At the beginning of our study period, $\sim 20 \mathrm{~km}$ of the upper end of Kangia Icefjord was packed with rigidly moving ice melange (Fig. 3). Between calving periods, the ice melange moved towards the mouth of the fjord at a speed similar to that of the glacier terminus. Three calving periods were observed before the clearing of the ice melange (1215 March, 2-5 April and 11-17 April) (Fig. 2), and our tracking results show melange speeds $>290 \mathrm{~m} \mathrm{~d}^{-1}$, seaward melange expansion and deformation in several narrow shear bands within the melange during each of these periods (Fig. 4). Immediately after a calving episode, the melange slowed down to below the speed of the glacier calving front and thereafter gradually reconsolidated and reaccelerated until reaching the speed of the advancing terminus (Amundson and others, 2010). The margin of the ice melange started to retreat on 14 April 2011 and the melange had cleared from the fjord by 8 May 2011 (see Fig. 3). After this date, only freely moving icebergs were detected by our offset-tracking dataset (and by visual inspection of the backscatter intensity images), apart from a few days in May when air temperatures below freezing caused temporary growth of sea ice.

\section{Kangerdlugssuaq Glacier}

Figure 5 presents Kangerdlugssuaq Glacier velocities at seven locations situated $\sim 1.0,2.5,4.0,5.0,7.5,9.0$ and $17.0 \mathrm{~km}$ upstream of the 17 March ice-front position (labelled locations 1-7, respectively, in Fig. 1b). At the lower part of the glacier, there was a general decreasing velocity trend between the start of our time series and midJune. Close to the ice front, the velocity decreased from 

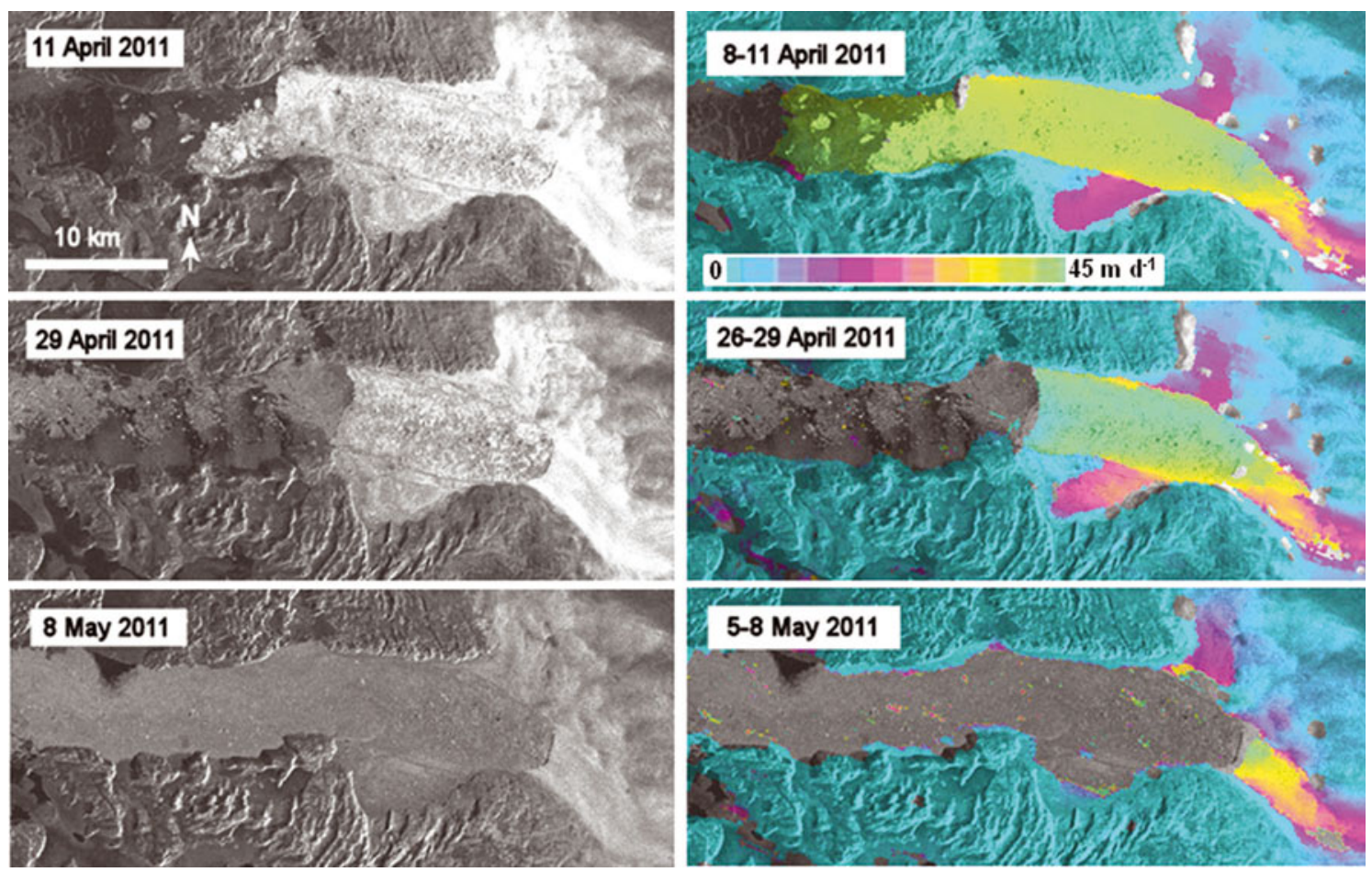

Fig. 3. SAR backscatter intensity images (greyscale) and SAR backscatter intensity images overlain by two-dimensional (2-D) offset-tracking velocity fields (in colour) showing the evolution of ice melange flow at Jakobshavn Isbræ.

$\sim 29.5$ to $\sim 25.2 \mathrm{~m} \mathrm{~d}^{-1}$ (15\% slowdown) over this period, and the magnitude of the slowdown decreased with increasing distance from the calving front. No significant trend in the velocity evolution was found beyond $\sim 10 \mathrm{~km}$ of the ice front during this time period. From the middle of June, a significant speed-up of up to $15 \%$ was observed over much of the glacier tongue, peaking between 21 and 27 June. The largest speed-up occurred $\sim 4-9 \mathrm{~km}$ upstream of the calving front (Fig. 5).

The Kangerdlugssuaq calving front advanced steadily throughout the period covered by the ERS-2 3 day campaign, only interrupted by one major calving episode (Fig. 5). Assuming no calving during the dates when SAR acquisitions failed, we observed 60 days of successive ice-front advance before this calving episode. Major fracture development occurred at the terminus at 13 May, and between 16 and 22 May the glacier retreated by $\sim 2 \mathrm{~km}$, losing a total calving-front area of $8.3 \pm 0.7 \mathrm{~km}^{2}$ (Table 1). After the calving episode, we observed a temporary increase in glacier velocity of $5.5 \%$ near the terminus.

Following a strong increase in air temperatures in early June, surface runoff commenced on 11 June at the lower part of the glacier, reaching a maximum of $1.6 \mathrm{~cm} \mathrm{~d}^{-1}$ during the period covered by our velocity time series (Fig. 5). Surface runoff thereafter peaked at $3.1 \mathrm{~cm} \mathrm{~d}^{-1}$ on 12 July and gradually diminished until the end of the summer melting season in mid-September (not shown). The distribution of supraglacial lakes varies significantly between different regions of the GrIS (Sundal and others, 2009; Selmes and others, 2011), and fewer and smaller lakes were observed in the Kangerdlugssuaq catchment compared with that of Jakobshavn Isbræ. While we identified approximately five minor lakes draining between 30 June and 3 July, the largest lakes at Kangerdlugssuaq did not drain within the time period covered by our 3 day velocity dataset.
Ice melange was observed in the near-terminus area throughout the time period covered by the ERS-2 3 day campaign (Fig. 6). Figure 5 shows melange velocity extracted at three locations $\sim 3,19$ and $26 \mathrm{~km}$ downstream of the Kangerdlugssuaq calving front (locations a-c, respectively, in Fig. 1b). At the beginning of our study period, the main fjord was choked with slow-flowing $\left(<1 \mathrm{~m} \mathrm{~d}^{-1}\right)$ ice, while the nearterminus melange speed was close to that of the calving front. About $20 \mathrm{~km}$ downstream of the calving front, compression occurred where ice melange was pushed against the slowflowing ice in the main fjord area. This zone gradually moved downstream over the following months, causing steady ice melange acceleration at location b. During the large calving event, the feature-tracking technique failed to determine ice melange velocities, but icebergs moving $>1 \mathrm{~km}$ in 3 days were identified from SAR backscatter images. As observed in Kangia Icefjord, the ice melange slowed down to below the speed of the glacier calving front immediately after the

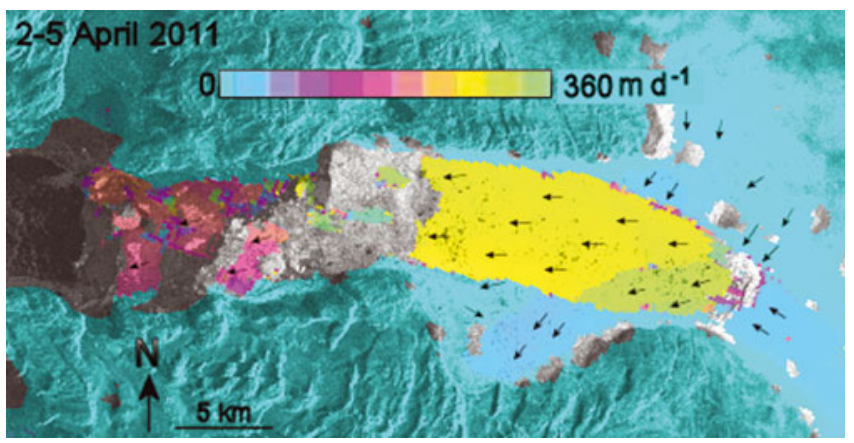

Fig. 4. SAR backscatter intensity image overlain by 2-D offsettracking velocity fields showing the ice melange velocity during the 2-5 April 2011 calving episode at Jakobshavn Isbræ. 


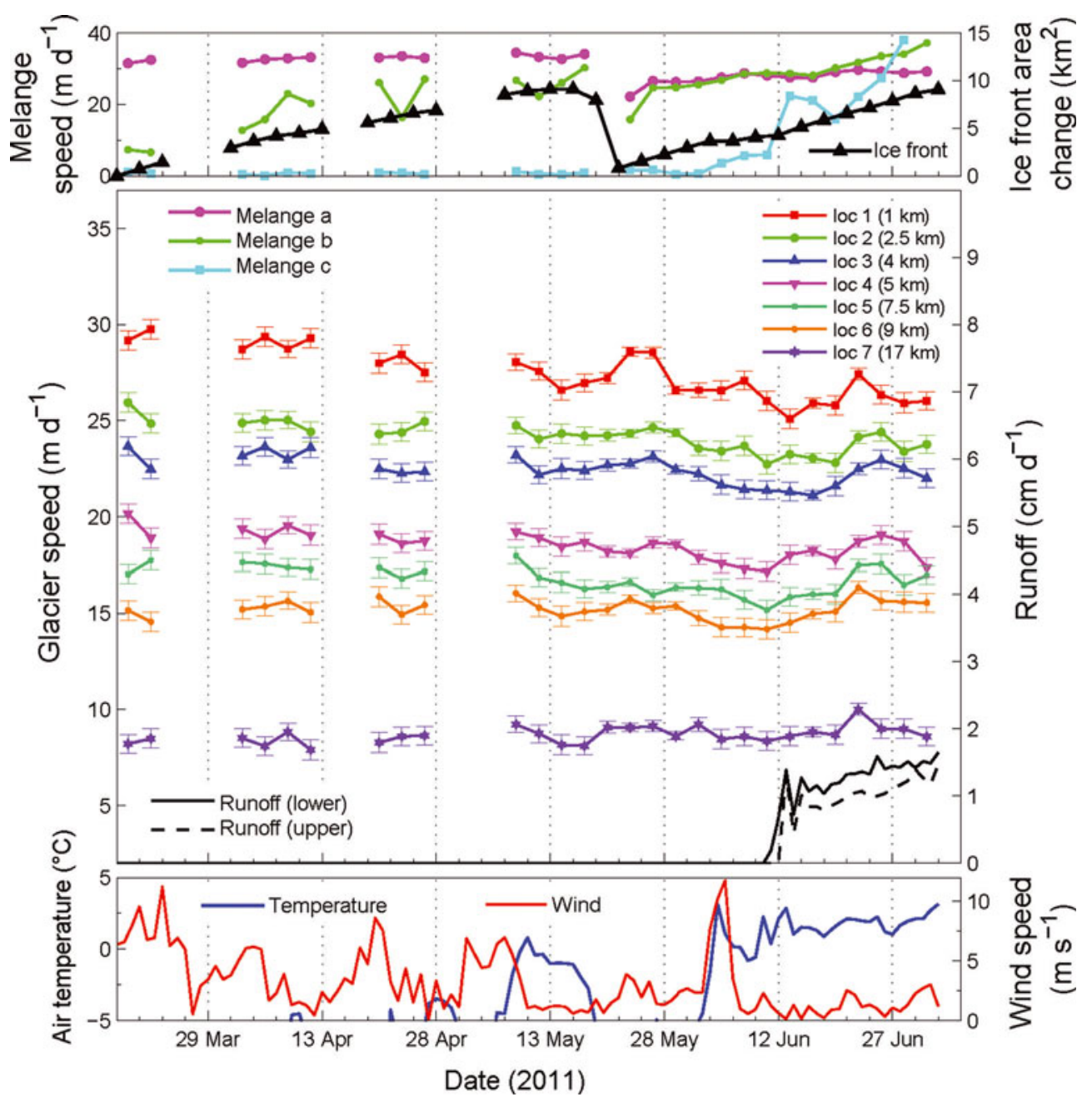

Fig. 5. Fluctuations in glacier velocity, ice melange velocity, calving-front area and modelled meteorological parameters at Kangerdlugssuaq Glacier. The wind vector component is shown in the along-fjord direction. Locations 1-7 and a-c are shown in Figure 1. Temperature and wind speed were extracted from the model gridcell covering the lower part of the glacier.

calving episode and thereafter reaccelerated until reaching the speed of the advancing terminus (Fig. 5). Speed-up at location c started at the beginning of June, and open fjord water was observed in front of the fast-flowing proglacial melange tongue $\sim 2$ weeks later.

\section{DISCUSSION}

Several processes may trigger changes in glacier speed, and separating the potential influence of these forcing mechanisms remains challenging (e.g. Joughin and others, 2012; Nick and others, 2012). Before the start of the summer melting season, we observe an inverse correlation between short-term fluctuations in speed and the pattern of calvingfront advance and retreat at both Jakobshavn and Kangerdlugssuaq glaciers, with the magnitude of the fluctuations decreasing up-glacier. This pattern of velocity variation suggests an initiation at the glacier terminus, with the most likely forcing mechanism being alterations in calving-front geometry and the concurrent change in resistance to the upstream ice (Joughin and others, 2008a; Nick and others, 2009). Model experiments have shown that loss of resistive stresses from the terminus area induces an instantaneous acceleration in flow at the calving front, which is transferred upstream through longitudinal stresses (Vieli and Nick, 2011). The longitudinal coupling distance is typically in the order of about ten ice thicknesses (Kamb and Echelmeyer, 1986), which agrees well with our observations of velocity fluctuations at the lower $\sim 10 \mathrm{~km}$ of the glacier trunks. Excluding the time period when surface runoff may affect glacier speed, we observe an average short-term nearterminus speed-up of $3.4 \%$ after Jakobshavn calving episodes. These results are consistent with the $\sim 3 \%$ velocity increase measured following calving events at Jakobshavn during 2007 (Amundson and others, 2008).

While change in terminus geometry is likely the dominant control on glacier velocity during the first part of our study period, this process cannot explain the acceleration observed at Kangerdlugssuaq towards the end of the time series. Drainage of surface runoff to the bed of the ice through moulins and crevasses has been shown to affect ice-sheet flow speed (e.g. Shepherd and others, 2009; Andersen and others, 2010), and the observed $<15 \%$ velocity increase at Kangerdlugssuaq commenced just after the onset of surface runoff (Fig. 5). Although marineterminating glaciers in Greenland generally display less sensitivity to variations in basal water pressure than landterminating glaciers, recent studies conclude that surface melt-induced basal lubrication controls seasonal velocity variations at Petermann Glacier (Nick and others, 2012) and several outlet glaciers in western Greenland (Howat and others, 2010). While we are unable to determine controls 

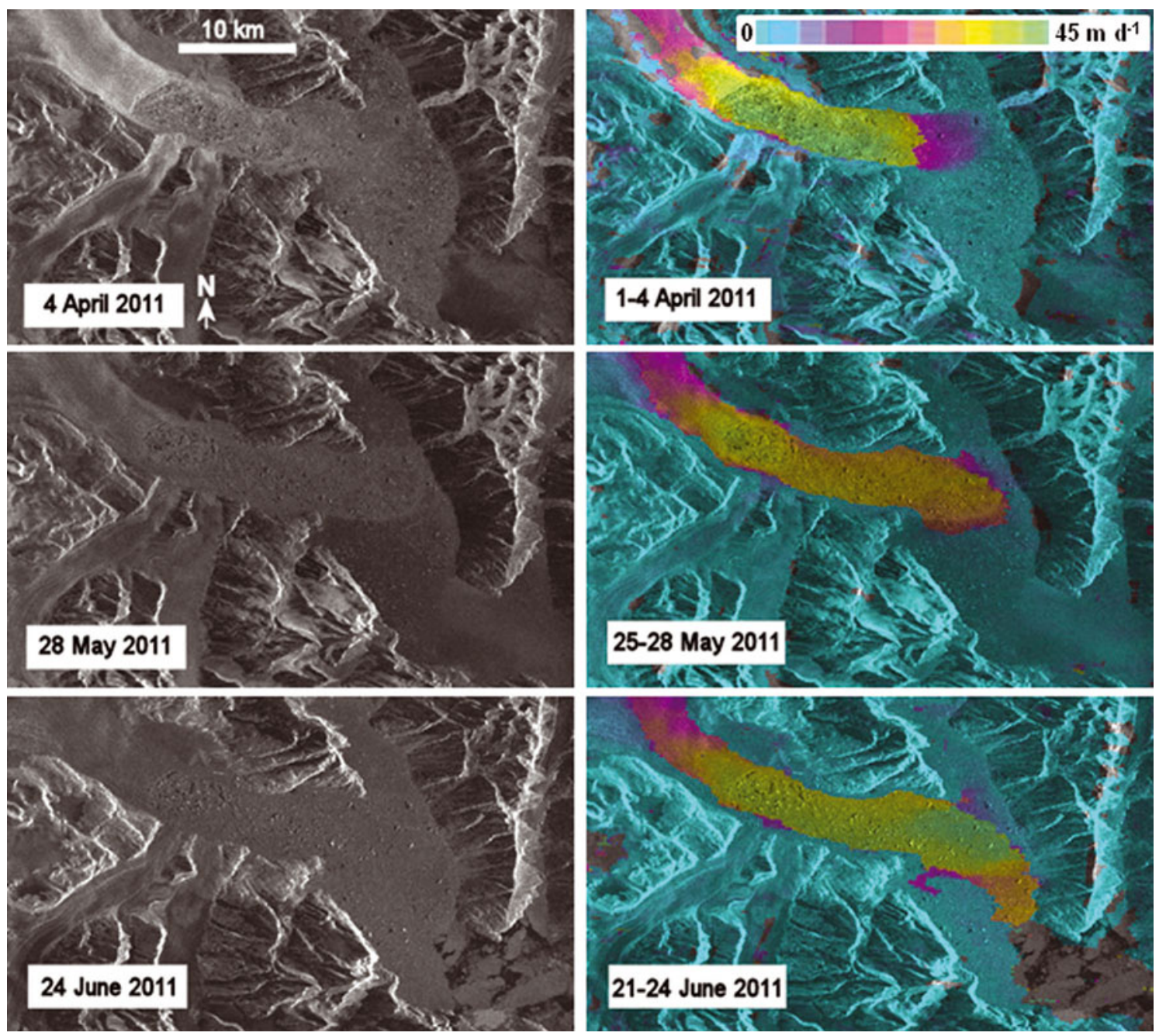

Fig. 6. SAR backscatter intensity images (greyscale) and SAR backscatter intensity images overlain by 2-D offset-tracking velocity fields (in colour) showing the evolution of ice melange flow at Kangerdlugssuaq Glacier.

on the late-summer velocity evolution, our dataset suggests that the early-summer acceleration observed at Kangerdlugssuaq is a response to local hydrological forcing as surface meltwater penetrates to an inefficient drainage bed, thus raising basal water pressure and causing increased sliding. The greater magnitude of speed-up and slightly earlier acceleration onset observed a few kilometres upstream of the calving front is consistent with the idea of forcing applied to regions above the glacier terminus and may be a result of this region having a better hydraulic connection to the glacier bed (Fig. 5). If the early-summer acceleration had been caused by perturbations at the glacier terminus, such as decreasing back-pressure from the weakening proglacial ice melange, we would have expected an enhanced velocity response near the terminus and a more subdued change further upstream. The slowdown observed during the last few days of our study period may be a result of a reduction in basal water pressure as the subglacial drainage efficiency increases (Schoof, 2010).

At Jakobshavn Isbræ, both surface runoff initiation and increased calving rate coincide with ice-flow acceleration at the lower part of the glacier trunk (Fig. 2). Based on the intimate link observed between changes in terminus position and glacier velocity during spring, we attribute much of this early-summer speed-up to loss in resistive stresses from the terminus area during the period of near-continuous calving-front retreat. This view is in agreement with previous observations and modelling experiments at Jakobshavn Isbræ that identify the seasonally varying terminus position and its potential indirect effects (e.g. thinning-induced change in effective pressure) as the dominant controls on the seasonal velocity cycle (Joughin and others, 2008a, 2012; Podrasky and others, 2012). While surface meltinduced basal lubrication may influence melt season velocities as observed on Kangerdlugssuaq Glacier, the simultaneous increase in calving rate and onset of surface runoff makes its potential effect on the Jakobshavn velocity difficult to quantify. The lower part of Jakobshavn Isbræ is highly crevassed (Echelmeyer and others, 1991), and some influence on glacier flow caused by penetration of surface meltwater to the bed in this area is likely.

Several mechanisms have been proposed to explain short-term variability in glacier calving rate (Sohn and others, 1998). One of these suggests that the existence of ice melange slows winter calving by exerting a small resistive force on the terminus (Sohn and others, 1998); Joughin and others, 2008a). Our high temporal resolution dataset covers the transitional period immediately prior to Jakobshavn ice melange clearing, during which a gradual weakening and disintegration of the ice melange occur. Consistent with previous findings (Joughin and others, 2008a), the mean surface temperatures were well below freezing during this 
period, indicating that the melange retreat was not triggered by atmospheric forcing. However, a period of increased wind speed just before the final clearing date may have served to further weaken and disperse the ice masses and thereby determine the exact timing of the clearing (Fig. 2). Our dataset shows that calving episodes are not prevented by the existence of $\sim 20 \mathrm{~km}$ of ice melange in Kangia Icefjord, but the calving-front retreats observed before the clearing of the melange are small compared with the frontal losses in summer (Joughin and others, 2008a; Amundson and others, 2010). We observe a close correlation between the timing of ice melange clearing and the maximum calving-front extent, which is consistent with the view that calving rate in winter is suppressed by the ice melange (Fig. 2). This view is also supported by the low calving rate observed at Kangerdlugssuaq where proglacial ice melange exists throughout our study period (Fig. 5). Factors specific to each individual glacier system (e.g. fjord geometry and ocean circulation) likely determine the difference observed in timing of ice melange break-up between different areas.

Floating and non-floating ice near the grounding line are often in tension and near fracture, and the presence of surface meltwater may enhance the ability of crevasses to penetrate the ice thickness and thereby promote calving events (Van der Veen, 1998; Vieli and Nick, 2011). Studies of seasonal variations in calving dynamics at Jakobshavn Isbræ suggest that this hydrofracturing process may contribute to the increased calving rate observed in summer (Sohn and others, 1998). Our Jakobshavn dataset shows an increase in calving rate after the onset of surface runoff, and while periods of calving-front advance lasting up to 15 days occurred between the clearing of ice melange and the onset of surface runoff, a near-continuous calving-front retreat was observed during the melting period (Fig. 2). These observations support the hypothesis that surface runoff may lead directly to increased calving and thereby enhanced summer calving-front retreat, although the effect of this process on the seasonality in calving for Jakobshavn Isbræ is likely less than that of the ice melange (Joughin and others, 2008a). Other processes that may influence the calving rate include seasonal variations in submarine melt driven by the fjord water temperature cycle and enhanced convection from subglacial discharge of summer surface meltwater, but information on such parameters is currently limited (Motyka and others, 2011; Vieli and Nick, 2011).

While our dataset only resolves calving episodes to within a 3 day period, Amundson and others $(2008,2010)$ found that a typical calving event lasts $\sim 1$ hour and involves overturning of several icebergs of full glacier thickness, which induces rapid ice melange flow acceleration. The velocity maps presented in this paper display the spatial variability of melange acceleration during calving periods, with nonuniform velocity patterns and partial loss of feature-tracking results (or complete loss in the case of the Kangerdlugssuaq calving episode) indicating longitudinal melange extension, internal deformation and a weakening of the ice melange matrix (Fig. 4). Between calving events, the proglacial ice melange is controlled by the advancing terminus, exhibiting a relatively spatially uniform flow pattern (see also Amundson and others, 2008, 2010; Joughin and others, 2008a).

While the alternation between periods of steady ice melange flow and rapid melange acceleration is controlled by the glacier terminus, ice melange dynamics are also likely to be influenced by the fjord geometry. Figure 4 shows a narrow $\sim 8 \mathrm{~km}$ long shear zone within the ice melange close to Jakobshavn Isbræ calving front that developed in the same location during all the (pre-melange clearing) calving episodes. Similarly, a deformation zone was observed throughout the melange velocity time series in the embayment area on the southern side of the fjord. These deformation bands are most likely caused by ice melange being pushed against the southern fjord walls and potentially an 'ice rumple' or submerged pinning point (Echelmeyer and others, 1991) located on the border between the main fjord and the embayment area. Pressure exerted on the ice melange from the south-southwest-flowing glacier on the northern side of the fjord likely contributes to the development of these features. Topographical constrictions may also slow the evacuation of ice melange from the fjord (Joughin and others, 2008a), causing strong compression in the areas where fast-flowing ice melange is pushed against nearly immobile ice masses as observed in the ice-choked fjord area downstream of the Kangerdlugssuaq Glacier terminus (Fig. 6).

\section{SUMMARY AND CONCLUSION}

We have produced a 3 day time series of ice velocity and icefront change at Greenland's Jakobshavn Isbræ and Kangerdlugssuaq Glacier using SAR data acquired during the ERS-2 3 day campaign. The dataset spans the period March-July 2011 and captures the first 4 weeks of the $\sim 3$ month long summer melting season. In both study areas, rapid velocity fluctuations were observed at the lower $\sim 10 \mathrm{~km}$ of the fastflowing ice tongue. At Jakobshavn Isbræ, where our dataset covers the initial phase of the seasonal calving-front retreat, the terminus exhibited ten calving episodes with a mean calving-front area loss of $1.29 \pm 0.4 \mathrm{~km}^{2}$. Ice-front advance dominated our study period at Kangerdlugssuaq Glacier, with only one major calving episode causing a frontal loss of $8.30 \pm 0.7 \mathrm{~km}^{2}$. Near the glacier fronts, we found a significant increase in speed following all calving episodes.

We observed an early melt season speed-up of up to $15 \%$ at Kangerdlugssuaq during a period of calving-front advance, which suggests that this glacier is sensitive to surface meltinduced changes in basal water pressure. This process may also contribute to the summer speed-up at Jakobshavn Isbræ, although we were unable to separate its potential effect on the glacier velocity from that of the retreating calving front. Before the onset of summer melting, the close link observed between short-term fluctuations in speed and the pattern of calving-front advance and retreat suggests that alternations in calving-front geometry and the concurrent change in resistive stresses at the terminus are the dominant control on shortterm variability in glacier velocity in both our study areas.

The Jakobshavn and Kangerdlugssuaq velocity time series show corresponding patterns of ice melange flow variability with a significant increase in melange speeds following calving episodes. Our results corroborate earlier findings (Amundson and others, 2008, 2010; Joughin and others, 2008a) and our high temporal resolution velocity maps display new spatial characteristics of the melange flow pattern. We identify calving-front dynamics and fjord geometry as the dominant controls on the observed cycle of rapid melange acceleration and deceleration and the internal deformation zones occurring within the ice melange. Comparisons of ice melange clearing date and calving-front dynamics support the view that ice melange formation slows 
the calving rate, although based on this dataset we cannot exclude the possibility that the melange and the calving front may be reacting simultaneously but independently to changes in ocean circulation or some other forcing.

\section{ACKNOWLEDGEMENTS}

This work was supported by the UK Natural Environment Research Council (NERC) National Centre for Earth Observation and by the European Union's Seventh Framework Programme (FP7) Ice2Sea project (publication No. 054). We thank the European Space Agency for providing SAR data from the ERS-2 3 day repeat campaign (project AO3108) and the Envisat mission (project C1P8743).

\section{REFERENCES}

Amundson JM, Truffer M, Lüthi MP, Fahnestock $M$, West $M$ and Motyka RJ (2008) Glacier, fjord, and seismic response to recent large calving events, Jakobshavn Isbræ, Greenland. Geophys. Res. Lett., 35(22), L22501 (doi: 10.1029/2008GL035281)

Amundson JM, Fahnestock M, Truffer M, Brown J, Lüthi MP and Motyka RJ (2010) Ice mélange dynamics and implications for terminus stability, Jakobshavn Isbræ, Greenland. J. Geophys. Res., 115(F1), F01005 (doi: 10.1029/2009JF001405)

Andersen ML, Nettles M, Elosegui P, Larsen TB, Hamilton GS and Stearns LA (2011) Quantitative estimates of velocity sensitivity to surface melt variations at a large Greenland outlet glacier. J. Glaciol., 57(204), 609-620 (doi: 10.3189/ 002214311797409785)

Benn D, Gulley J, Luckman A, Adamek A and Glowacki PS (2009) Englacial drainage systems formed by hydrologically driven crevasse propagation. J. Glaciol., 55(191), 513-523 (doi: 10.3189/002214309788816669)

Bevan SL, Luckman AJ and Murray T (2012) Glacier dynamics over the last quarter of a century at Helheim, Kangerdlugssuaq and 14 other major Greenland outlet glaciers. Cryosphere, 6(5), 923-937 (doi: 10.5194/tc-6-923-2012)

Christoffersen P, O'Leary M, Van Angelen JH and Van den Broeke $M$ (2012) Partitioning effects from ocean and atmosphere on the calving stability of Kangerdlugssuaq Glacier, East Greenland. Ann. Glaciol., 53(60 Pt 2), 249-256

Das SB and 6 others (2008) Fracture propagation to the base of the Greenland Ice Sheet during supraglacial lake drainage. Science, 320(5877), 778-781 (doi: 10.1126/science.1153360)

DiMarzio J, Brenner A, Schutz R, Shuman CA and Zwally HJ (2007) GLAS/ICESat $1 \mathrm{~km}$ laser altimetry digital elevation model of Greenland. National Snow and Ice Data Center, Boulder, CO. Digital media: nsidc.org/data/nsidc-0305.hml

Echelmeyer K and Harrison WD (1990) Jakobshavns Isbræ, West Greenland: seasonal variations in velocity - or lack thereof. J. Glaciol., 36(122), 82-88

Echelmeyer K, Clarke TS and Harrison WD (1991) Surficial glaciology of Jakobshavns Isbræ, West Greenland: Part I. Surface morphology. J. Glaciol., 37(127), 368-382

Holland DM, Thomas $\mathrm{RH}$, de Young B, Ribergaard $\mathrm{MH}$ and Lyberth B (2008) Acceleration of Jakobshavn Isbræ triggered by warm subsurface ocean waters. Nature Geosci., 1(10), 659-664 (doi: 10.1038/ngeo316)

Howat IM, Box JE, Ahn Y, Herrington A and McFadden EM (2010) Seasonal variability in the dynamics of marine-terminating outlet glaciers in Greenland. J. Glaciol., 56(198), 601-613 (doi: 10.3189/002214310793146232)

Joughin I, Abdalati W and Fahnestock MA (2004) Large fluctuations in speed on Greenland's Jakobshavn Isbræ glacier. Nature, 432(7017), 608-610 (doi: 10.1038/nature03130)

Joughin I and 7 others (2008a) Continued evolution of Jakobshavn Isbræ following its rapid speedup. J. Geophys. Res., 113(F4), F04006 (doi: 10.1029/2008JF001023)
Joughin I, Das SB, King MA, Smith BE, Howat IM and Moon T (2008b) Seasonal speedup along the western flank of the Greenland Ice Sheet. Science, 320(5877), 781-783 (doi: 10.1126/science.1153288)

Joughin I and 8 others (2008c) Ice-front variation and tidewater behavior on Helheim and Kangerdlugssuaq Glaciers, Greenland. J. Geophys. Res., 113(F1), F01004 (doi: 10.1029/ 2007JF000837)

Joughin I and 6 others (2012) Seasonal to decadal scale variations in the surface velocity of Jakobshavn Isbræ, Greenland: observation and model-based analysis. J. Geophys. Res., 117(F2), F02030 (doi: 10.1029/2011JF002110)

Kamb B and Echelmeyer KA (1986) Stress-gradient coupling in glacier flow: IV. Effects of the T term. J. Glaciol., 32(112), 342-349

Luckman A, Murray T, de Lange R and Hanna E (2006) Rapid and synchronous ice-dynamic changes in East Greenland. Geophys. Res. Lett., 33(3), L03503 (doi: 10.1029/2005GL025428)

Moon T, Joughin I, Smith B and Howat I (2012) 21st-century evolution of Greenland outlet glacier velocities. Science, 336(6081), 576-578

Motyka RJ, Truffer M, Fahnestock M, Mortensen J, Rysgaard S and Howat I (2011) Submarine melting of the 1985 Jakobshavn Isbræ floating tongue and the triggering of the current retreat. J. Geophys. Res., 116(F1), F01007 (doi: 10.1029/2009JF001632)

Nick FM, Vieli A, Howat IM and Joughin I (2009) Large-scale changes in Greenland outlet glacier dynamics triggered at the terminus. Nature Geosci., 2(2), 110-114 (doi: 10.1038/ ngeo394)

Nick FM and 8 others (2012) The response of Petermann Glacier, Greenland, to large calving events, and its future stability in the context of atmospheric and oceanic warming. J. Glaciol., 58(208), 229-239 (doi: 10.3189/2012JoG11J242)

Podrasky D, Truffer M, Fahnestock MA, Amundson JM, Cassotto R and Joughin I (2012) Outlet glacier response to forcing over hourly to interannual timescales, Jakobshavn Isbræ, Greenland. J. Glaciol., 58(212), 1212-1226 (doi: 10.3189/2012JoG12J065)

Pritchard H, Murray T, Luckman A, Strozzi T and Barr S (2005) Glacier surge dynamics of Sortebræ, East Greenland, from synthetic aperture radar feature tracking. J. Geophys. Res., 110(F3), F03005 (doi: 10.1029/2004JF000233)

Reeh N, Thomsen HH, Higgins AK and Weidick A (2001) Sea ice and the stability of north and northeast Greenland floating glaciers. Ann. Glaciol., 33, 474-480 (doi: 10.3189/ 172756401781818554)

Rignot E and Kanagaratnam P (2006) Changes in the velocity structure of the Greenland Ice Sheet. Science, 311(5673), 986-990 (doi: 10.1126/science.1121381)

Rignot E, Koppes M and Velicogna I (2010) Rapid submarine melting of the calving faces of West Greenland glaciers. Nature Geosci., 3(3), 141-218 (doi: 10.1038/ngeo765)

Rosenau R, Schwalbe E, Maas H-G, Baessler M and Dietrich R (in press) Grounding line migration and high-resolution calving dynamics of Jakobshavn Isbræ, West Greenland. J. Geophys. Res., 118 (doi: 10.1029/2012JF002515)

Schoof C (2010) Ice-sheet acceleration driven by melt supply variability. Nature, 468(7325), 803-806 (doi: 10.1038/ nature09618)

Seale A, Christoffersen P, Mugford RI and O'Leary M (2011) Ocean forcing of the Greenland Ice Sheet: calving fronts and patterns of retreat identified by automatic satellite monitoring of eastern outlet glaciers. J. Geophys. Res., 116(F3), F03013 (doi: 10.1029/ 2010JF001847)

Selmes N, Murray T and James TD (2011) Fast draining lakes on the Greenland Ice Sheet. Geophys. Res. Lett., 38(15), L15501 (doi: 10.1029/2011GL047872)

Shepherd A, Hubbard A, Nienow P, McMillan M and Joughin I (2009) Greenland ice sheet motion coupled with daily melting in late summer. Geophys. Res. Lett., 36(1), L01501 (doi: 10.1029/2008GL035758) 
Sohn HG, Jezek KC and Van der Veen CJ (1998) Jakobshavn Glacier, West Greenland: 30 years of spaceborne observations. Geophys. Res. Lett., 25(14), 2699-2702 (doi: 10.1029/ 98GL01973)

Sole AJ and 6 others (2011) Seasonal speedup of a Greenland marine-terminating outlet glacier forced by surface meltinduced changes in subglacial hydrology. J. Geophys. Res., 116(F3), F03014 (doi: 10.1029/2010JF001948)

Straneo F and 7 others (2010) Rapid circulation of warm subtropical waters in a major glacial fjord in East Greenland. Nature Geosci., 3(33), 182-186 (doi: 10.1038/ngeo764)

Strozzi T, Luckman A, Murray T, Wegmuller $U$ and Werner CL (2002) Glacier motion estimation using satellite-radar offsettracking procedures. IEEE Trans. Geosci. Remote Sens., 40(11), 2834-2391 (doi: 10.1109/TGRS.2002.805079)

Sundal AV, Shepherd A, Nienow P, Hanna E, Palmer S and Huybrechts P (2009) Evolution of supra-glacial lakes across the Greenland Ice Sheet. Remote Sens. Environ., 113(10), 2164-2171 (doi: 10.1016/j.rse.2009.05.018)

Sundal AV, Shepherd A, Nienow P, Hanna E, Palmer S and Huybrechts P (2011) Melt-induced speed-up of Greenland ice sheet offset by efficient subglacial drainage. Nature, 469(7331), 521-524 (doi: 10.1038/nature09740)

Thomas RH (2004) Force-perturbation analysis of recent thinning and acceleration of Jakobshavn Isbræ, Greenland. J. Glaciol., 50(168), 57-66 (doi: 10.3189/172756504781830321)
Van Angelen JH and 6 others (2012) Sensitivity of Greenland Ice Sheet surface mass balance to surface albedo parameterization: a study with a regional climate model. Cryos. Discuss., 6(2), 1531-1562 (doi: 10.5194/tcd-6-1531-2012)

Van den Broeke $M$ and 8 others (2009) Partitioning recent Greenland mass loss. Science, 326(5955), 984-986 (doi: 10.1126/science.1178176)

Van der Veen CJ (1998) Fracture mechanics approach to penetration of surface crevasses on glaciers. Cold Reg. Sci. Technol., 27(1), 31-47

Van de Wal RSW and 6 others (2008) Large and rapid melt-induced velocity changes in the ablation zone of the Greenland Ice Sheet. Science, 321(5885), 111-113 (doi: 10.1126/ science.1158540)

Van Meijgaard E and 6 others (2008) The KNMI regional atmospheric climate model RACMO version 2.1. (KNMI Technical Report TR-302) Royal Netherlands Meteorological Institute (KNMI), De Bilt

Vieli A and Nick FM (2011) Understanding and modelling rapid dynamic changes of tidewater outlet glaciers: issues and implications. Surv. Geophys., 32(4-5), 437-458 (doi: 10.1007/ s10712-011-9132-4)

Zwally HJ, Abdalati W, Herring T, Larson K, Saba J and Steffen K (2002) Surface melt-induced acceleration of Greenland icesheet flow. Science, 297(5579), 218-222 (doi: 10.1126/ science.1072708) 